\title{
Study of Wool Characteristics in the Aranese Ovine Breed
}

\author{
Estudio de las Características de la Lana en la Raza Ovina Aranesa
}

\author{
"P.M Parés; ${ }^{* *}$ J. Jordana \& ${ }^{* * * *}$ R. Pérezgrovas
}

\begin{abstract}
PARÉS, P. M.; JORDANA, J. \& PÉREZGROVAS, R. Study of wool characteristics in the Aranese ovine breed. Int. J. Morphol., 29(1):123-126, 2011.

SUMMARY: To date, no ethnological study on the wool characteristics of the Spanish Aranese ovine breed has been published. Fifty three animals belonging to this breed are tested as fleece samples. Each sample is analyzed for fleece type and length, yield by isoalcohol scouring, fiber length for each kind of fiber, variation in fiber diameter, and proportions of non-medullated and medullated or kemp fibers. Fiber length appears shorter than that previously reported for the breed by other authors. Fleeces of the Aranese sheep breed can be described as square, simple, "semi-open" and short with a relatively high yield by isoalcohol scouring and low medullation levels, thus indicating good potential quality and greater suitability for potential processing than other similar meat breeds.
\end{abstract}

KEY WORDS: Fiber diameter; Fleece; Kemp; Medullation; Sheep; Yield.

\section{INTRODUCTION}

The Aranese sheep breed is one of the three local sheep breeds that exist in Catalonia (NE Spain). The other two sheep breeds common in the country are Ripollesa and Xisqueta (Esteban, 2003). Although all of these breeds are used mainly for meat production as wool is sold as a by-product at a very low price, even so, wool data from the Aranese must be seen as an important contribution to the breed ethnological characterization which is precisely the purpose of this study.

The native region of the breed is the Aran Valley. The Aran Valley is a small region $\left(620.47 \mathrm{~km}^{2}\right)$ in the Pyrenees Central Mountains in the NW part of Catalonia, which is a political region of Spain but culturally belongs to Occitania land, in France. It is the source of the Garonne River and one of the highest valleys of the Pyrenees. The region is characterized by an Atlantic climate, due to this peculiar orientation on the $\mathrm{N}$ face of the Pyrenees, which is different from the other Spanish valleys in the area. It is a green and fertile area of forests and meadows, enclosed by jagged mountain summits. Census of the breed is below 2.500 individuals (Parés, 2008).
The importance of wool characteristics and their variations have long been recognized as valuable tools to describe a breed of sheep (Esteban; Parés et al., 2007a); Sánchez-Belda \& Sánchez-Trujillano, 1986). Fleece characteristics have also recently been used as valuable technique in tracing ovine breed phylogenies (Parés et al., 2007b).

Nevertheless, few extensive studies on the features of the wool characteristics of local sheep breeds have been undertaken or an examination of these characteristics as ethnological traits. To the best of our knowledge there has been no examination of global data of fleece characteristics for the Aranese ovine breed.

The objective of this study was to investigate the wool characteristics of the Aranese sheep breed. Given that Aranese sheep are subjected to a similar environment and management practices within a confined geographical region, this study can be seen as the first full description of Aranese wool from an ethnological point of view.

\footnotetext{
* Dep. Producció Animal. ETSEA. Univ. of Lleida. Catalunya, Spain.

** Unitat de Ciència Animal, Dep. de Ciència Animal i dels Aliments, Facultat de Veterinària, Universitat Autònoma de Barcelona, Spain.

**** Laboratorio de Calidad de Lana.1 Instituto de Estudios Indígenas. Universidad Autónoma de Chiapas. San Cristóbal de Las Casas, Chiapas, México.
} 


\section{MATERIAL AND METHOD}

The trial was carried out at 3 farms in the Aranese region of the Pyrenees (flock A: 8 sampled animals; flock B: 36 sampled animals; flock C: 9 sampled animals). Sheep were managed under extensive grazing and housed over winter nights.

A sample of 53 pure animals ( 5 males and 48 females,) was randomly selected from those herds to obtain a representative sample of the breed (flock A: a herd of 21 animals; flock B: a herd of 575 animals; flock C: a herd of 88 animals). The selected sheep fleeces were sampled in fall (animals shed in spring). Fleece samples were manually pulled from the shoulder region. Each fleece was subsequently evaluated for fleece type (squared, trapezoidshape, brush-shape or conical) and measured for length, isoalcohol scouring yield, fiber length for each type of fiber, variation in fiber diameter, and proportions of nonmedullated, medullated (kemp) fibers in the fleece. Fleece staple length was determined as the average length of at least 10 randomly measured staples from the greasy fleece sample. Yield was determined by isoalcohol scouring (2 changes of isoalcohol). Greasy and clean samples were weighed after conditioning at room temperature for 24 hours and subsequently drying at $21^{\circ} \mathrm{C}$ and $55 \%$ relative humidity for 48 hours (European analysis standards). Fiber diameter and proportions of fiber types were measured by lanometer; a total of 2,184 measures were taken for diameter. Fibers were classified as non-medullated and fully medullated, the proportion of each type expressed as a percentage of the total fiber number was calculated. F30 was calculated as the percentage of fibers with a diameter $>30 \mu$. An overall mean

Table I. Mean values \pm standard deviation for the raw traits measured.

\begin{tabular}{ll}
\hline Measurement & \multicolumn{1}{c}{ Mean value } \\
\hline Fleece type & \multicolumn{1}{c}{ Squared } \\
Staple length $(\mathrm{cm})$ & $4.3 \pm 0.71$ \\
Yield by isoalcohol scouring $(\%)$ & $85.7 \pm 9.31$ \\
Fiber diameter $(\mu)$ & $29.5 \pm 2.87$ \\
Non-medullated: medullated fibers & $127: 1$ \\
Length of non-medullated fibers $(\mathrm{cm})$ & $3.8 \pm 1.40$ \\
$\%$ non-medullated & $99.0 \pm 13.11$ \\
Length of medullated fibers $(\mathrm{cm})$ & $1.3 \pm 0.50$ \\
$\%$ medullated fibers & $1.0 \pm 1.32$ \\
F30 $(\%)$ & 38.9 \\
Assimetry coefficient of diameter $^{\circ}$ & 2.734 \\
Kurtosis coefficient of diameter & ${ }^{\circ}$ \\
\hline
\end{tabular}
${ }^{\circ} \mathrm{p}<0.001$. for each animal was calculated as the average of each measurement. Crimps were not studied.

Ethical approval was not required as sampling does not represent any injury to animals.

Data was analyzed using PAST - "Paleontological Statistics Software Package for Education and Data Analysis" (Hammer et al., 2001). No distinction between racial Aranese phenotypes (white, black, black \& white "beret", "pigallada" and "moscarda" respectively-, and reddish -"capiroia"-) was made, although only 11 sampled animals were not white.

\section{RESULTS AND DISCUSSION}

Data is presented in Table I. In Table II there is the canonical analysis considering 2 environmental variables. Canonical analysis is a multivariate technique which is concerned with determining the relationships between groups of variables in a data set. The data set is split into two groups, based on some common characteristics.

Aranese animals are characterized by having square ("even"), simple, short fleeces. The staple length appears shorter than those previously reported $(6-8 \mathrm{~cm}$ according to Esteban). The relative general high variation could be explained because the breed has not been subjected to wool selection criteria but exclusively to meat selection criteria,

Table II. Canonical analysis considering 2 environmental variables.

\begin{tabular}{lcl}
\hline Measurement & Can 1 & Can2 \\
\hline F30 & 1.059 & -0.001 \\
Fiber diameter & 0.515 & -0.456 \\
CV fiber diameter & 0.326 & -1.240 \\
Yield by isoalcohol scouring & 0.194 & -0.508 \\
\% medullated fibers & 0.169 & -7.823 \\
Assimetry coefficient & 0.060 & -1.042 \\
Length of medullated fibers & 0.019 & -1.926 \\
Kurtosis coefficient & -0.172 & 0.653 \\
\% non-medullated & -0.638 & -0.893 \\
Non-medullated: medullated fibers & -0.792 & 1.221 \\
Length of non-medullated fibers & -1.362 & -2.707 \\
\hline
\end{tabular}


with no importance given to wool quality and/or yield. Nevertheless Aranese breeders have intuitively had a tendency to avoid longer fleeces because coarse wool collects rough material and dirt.

The fiber diameter does not depend either on climate or on feeding (Gutiérrez, 1998). In our data it appears as the most discriminative variable. The values indicate a range between 9 to $135 \mu$ with a marked tendency towards finer fibers (kurtosis coefficient is slightly higher and assimetry coefficient is low). The skewness values are similar to other meat breeds (Pérez, 1998). Mayo et al. (1994) noted that the distribution of fiber diameter is of importance in determining wool quality, both for the appearance and comfort of the finished garment and for its performance during wool processing. Fiber diameters in Aranese sheep display less variation than other sheep breeds (Altin \& Okut, 1996; Pérez).

Yield by isoalcohol scouring is high, thus indicating low levels of grease. The cold climate in the Aran Valley animals do not need to sweat- and the high proportion of fine fibers (fine fibers and grease are proportionally related) could explain this fact. As fleece grease has an agglutinative effect on fiber tips, its low presence means that fleeces are not compact and fleece can be defined as "semi-open".

The presence of kemp in the wool is considered to be a serious defect and could be of great significance if the wool were to be sold. The medulla does not absorb dyes in the same way as fiber cortex, and it also causes problems during processing because of fiber breakage. Medullated fibers also have an effect on the handling, stiffness and prickliness of resultant fabrics. The low medullation levels in the Aranese sheep of about $1 \%$ kemp is a significant, positive characteristic of its fiber quality.

According to the obtained data, Aranese fleeces would be classified as Vth class on the Spanish scale, as "medium" (the ancient "Merino 3/8 blood") on the American scale (Ensminger, 1970) and "croisé" on the Wuliji scale (Wuliji et al., 1999). In the traditional ethnological classification the breed belongs to the "entrefine" trunk, which includes other geographically neighbouring French breeds such Auraise, Baregeoise, Castillonaise and Tarasconnaise (Parés et al., 2007b). This trunk also includes other Spanish breeds such as Ansotana, Rasa Aragonesa, Roncalesa and Ripollesa (Esteban). Their square, simple, "semi-open", short fleeces with relatively high yield by isoalcohol scouring and with low medullation levels, although far from Merino values (Mueller et al., 2001), indicate good potential quality, at least at an industrial level. In comparison with Turkish breeds, such as Ankarman and Malya (Çolakog `lu \& Özbeyaz, 1999), the obtained results show clear differences that are less comparable with Turkish merinos (Tekin et al., 1999) thus reinforcing the potential use of wool analysis in ethnological classification.

The wool quality in the Aranese breed is more suitable for potential processing than other similar meat breeds (Pérez) which must be kept in mind while achieving improved productive goals for Aranese sheep in a possible more thriving wool market.

PARÉS, P. M.; JORdanA, J. \& PÉREzGrovas, R. Estudio de las características de la lana en la raza ovina Aranesa. Int. J. Morphol., 29(1):123-126, 2011.

RESUMEN: Hasta el momento, ningún estudio etnológico sobre las características de la lana de la variedad española ovina Aranesa ha sido publicado. Cincuenta y tres animales de esta raza han sido analizados a partir de muestras de su vellón. Cada muestra se analizó para el tipo de vellón y longitud, su rendimiento mediante isoalcohol desgrasado, longitud de las fibras para cada tipo de fibra, variación en el diámetro de la fibra, y las proporciones de fibras no meduladas y meduladas o fibras kemp. La longitud de las fibras parece más corta que la reportada para esta raza por otros autores. El vellón de la raza ovina Aranesa se puede describir como cuadrado, simple, "semi-abierto" y corto, con un rendimiento relativamente alto por desengrasado mediante isoalcohol y bajos niveles de medulación, lo que indica la buena calidad potencial y mayor oportunidad para el procesamiento potencial que otras razas similares de carne.

PALABRAS CLAVE: Diámetro de la fibra; Vellón; Kemp; Medulación; Ovejas; Rendimiento.

\section{REFERENCES}

Altin, T. \& Okut, H. The Uniformity of Karakas Lamb Wool in Terms of Length and Fineness. Turk. J. Vet. Anim. Sci., 20:405-10, 1996.

Çolakog $`$ lu, N. \& Özbeyaz, C. Comparison of some production traits in Malya and Akkaraman sheep. Turk. J. Vet. Anim. Sci., 23:351-60, 1999.

Ensminger, M. E. Sheep and Wool Science. Illinois, The Interstate Printers \& Publishers Inc., 1970. 
Esteban, C. Razas ganaderas Españolas. II. Ovinas. Madrid, FEAGAS \& MAPA, 2003.

Gutiérrez, G. Anàlisis microscópico para determinar las variaciones estacionales en la calidad de lana en los tres fenotipos del borrego Chiapas. Thesis. Facultad de Medicina Veterinaria y Zootecnia. Universidad Autónoma de Chiapas, Tuxtla Gutiérrez, Chiapas, 1998.

Hammer, Ø.; Harper, D. A. T. \& Ryan, P. D. PAST: Paleontological Statistics Software Package for Education and Data Analysis. Palaeontologia Electronica, 4, 2001. Avalaible in: http://palaeoelectronica.org/2001_1/past/issue1_01.html

Mayo, O.; Crook, B.; Lax, J.; Swan, A. \& Hancock, T. W. The determination of fiber diameter distribution. Wool Tech. Sheep Breed., 42:231-6, 1994.

Mueller, J. P.; Duga, L., Giraudo, C. \& Bidinost, F. Calidad de vellones en una majada Merino de la Patagonia. Revista de Investigaciones Agropecuarias, 30:101-13, 2001.

Parés, P. M. Caracterització Estructural i Racial de la Raça Ovina Aranesa. Tesis Doctoral. Universidad Autònoma de Barcelona, Barcelona, 2008.

Parés, P. M.; Pérezgrovas, R. \& Jordana, J. The Aura-Campan ovine breed: a reminiscence of merinisation in the Central Pyrenees. REDVET, VIII, 2007a. Avalaible in: http:/ /www.veterinaria.org/revistas/redvet/n101007/ 100702.pdf

Parés, P. M.; Pérezgrovas, R. \& Jordana, J. Comparative Analysis of Fleece in different Spanish and French Sheep Breeds. Quevedo, Ecuador, VIII Simposio Iberoamericano sobre Conservación y Utilización de Recursos Zoogenéticos, 2007b.

Pérez, C. Evaluación de las Características Macroscópicas de la Lana que influyen sobre la Calidad del Vellón en el Borrego de Chiapas. Thesis. Fac. de Medicina Veterinaria y Zootecnia. Univ. Autónoma de Chiapas, Tuxtla Gutiérrez, Chiapas, México, 1998.

Sánchez-Belda, A. \& Sánchez-Trujillano, M. C. Razas ovinas españolas. Madrid, Ministerio de Agricultura, Pesca y Alimentación, 1986.

Tekin, M. E.; Kadak, R., Akmaz, A. \& Ergín, A. The Wool Characteristics of Turkish Merino, German Blackheaded Mutton Sheep, Hampshire Down, Lincoln Longwool,
Corriedale and their F1 and B1 Crossbreed Sheeps. Turk. J. Vet. Anim. Sci., 23:391-6, 1999.

Wuliji, T. D.; Odds, K. G. L.; Andrews, R. N. \& Turner, P. R. Response to selection for ultrafine Merino sheep in New Zealand: I. Wool production and wool characteristics of ultrafine fiber diameter selected and control Merino year-lings. Livest. Prod. Sci., 58:33-44, 1999.

Correspondence to:

P. M. Parés

Dep. Producció Animal

ETSEA. University of Lleida

Catalunya - SPAIN

Email adress: peremiquelp@prodan.udl.cat

Received: 08-09-2010

Accepted: 04-11-2010 